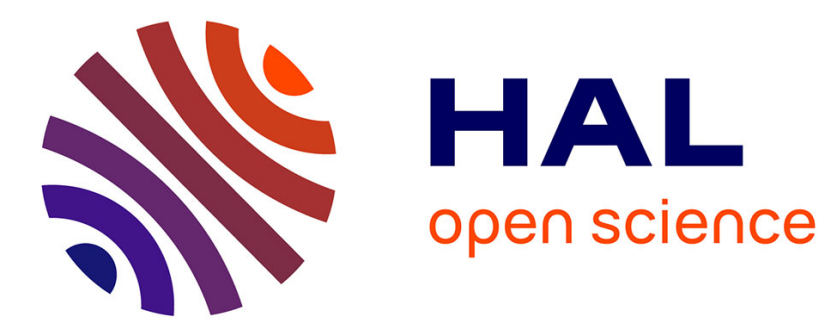

\title{
Polymeric Bis(dipyrrinato) Zinc(II) Nanoparticles as Selective Imaging Probes for Lysosomes of Cancer Cells
}

Johannes Karges, Olivier Blacque, Hui Chao, Gilles Gasser

\section{To cite this version:}

Johannes Karges, Olivier Blacque, Hui Chao, Gilles Gasser. Polymeric Bis(dipyrrinato) Zinc(II) Nanoparticles as Selective Imaging Probes for Lysosomes of Cancer Cells. Inorganic Chemistry, In press, 10.1021/acs.inorgchem.9b02019 . hal-02280173

\section{HAL Id: hal-02280173 \\ https://hal.science/hal-02280173}

Submitted on 6 Sep 2019

HAL is a multi-disciplinary open access archive for the deposit and dissemination of scientific research documents, whether they are published or not. The documents may come from teaching and research institutions in France or abroad, or from public or private research centers.
L'archive ouverte pluridisciplinaire HAL, est destinée au dépôt et à la diffusion de documents scientifiques de niveau recherche, publiés ou non, émanant des établissements d'enseignement et de recherche français ou étrangers, des laboratoires publics ou privés. 


\section{Polymeric Bis(dipyrrinato) Zinc(II) Nanoparticles}

\section{as Selective Imaging Probes for Lysosomes of}

\section{Cancer Cells}

Johannes Karges, ${ }^{a}$ Olivier Blacque, ${ }^{b}$ Hui Chao, ${ }^{c, *}$ and Gilles Gasser ${ }^{a, *}$

a Chimie ParisTech, PSL University, CNRS, Institute of Chemistry for Life and Health Sciences, Laboratory for Inorganic Chemical Biology, 75005 Paris, France.

b Department of Chemistry, University of Zurich, Winterthurerstrasse 190, CH-8057, Zurich, Switzerland.

c MOE Key Laboratory of Bioinorganic and Synthetic Chemistry, School of Chemistry, Sun Yat-sen University, 510275 Guangzhou, People's Republic of China.

Keywords: Bioinorganic Chemistry, Imaging, Inorganic Chemical Biology, Nanoparticles, Targeting. 


\begin{abstract}
Fluorescence imaging is a powerful tool in biomedical research. It has been frequently used to uncover or better understand physiological mechanisms in disease-related processes such as cancer. The majority of chromophores used for imaging are based on a 4,4-difluoro-4-bora3a,4a-diaza-s-indacene (BODIPY) scaffold. However, their applications are limited due to their poor water solubility as well as poor cancer cell selectivity. To circumvent these drawbacks, we present herein the use of bis(dipyrrinato)zinc(II) complexes. As this class of compounds is associated with a quenching effect of the excited state in water, the lead compound of this study (3) was encapsulated in a polymer matrix with biotin as a targeting moiety (3-NP). This encapsulation improved the water solubility, overcame the quenching effects in water as well as allowed selective accumulation in the lysosomes with a bright fluorescence signal in monolayer cells as well as 3D multicellular tumour spheroids (MCTS). As benefit from the biotin targeting moiety, the nanoparticles were majorly taken up by the sodium dependent multivitamin transporter (SMVT) which is overexpressed in various cancers cells and selectively accumulated in cancerous cells over non-cancerous cells.
\end{abstract}




\section{INTRODUCTION}

The ability to use imaging techniques either on a microscopic cellular level or even on humans has strongly influenced modern medical research. Among others, fluorescence imaging has received increasing attention over the last decades as this method was found to efficiently monitor physiological processes. Of special interest is the monitoring of disease-related organisms or cells. ${ }^{1-2}$

Among the different classes of imaging compounds investigated, chromophores based on a 4,4-difluoro-4-bora-3a,4a-diaza-s-indacene (BODIPY) scaffold are of special interest. These compounds are associated with a strong UV/Vis absorbance, chemical and photostability as well as sharp and strong fluorescence. For these reasons, these dyes are currently been used for numerous cellular applications including chemosensors, fluorescent switches as well as in the labelling of protein or DNA. ${ }^{3-9}$ However, the applications of these dyes are generally limited by their poor water solubility and cancer cell selectivity. To overcome these limitations, different dyes have been linked to a targeting moiety or formulations have been investigated to promote selective drug delivery. ${ }^{10-12}$

Beside boron complexes, dipyrrin ligands are also able to coordinate other metal ions such as $\mathrm{Ni}(\mathrm{II}), \mathrm{Zn}(\mathrm{II}), \mathrm{Cu}(\mathrm{II}), \mathrm{Fe}(\mathrm{III}), \mathrm{Rh}(\mathrm{III})$ and $\mathrm{Co}(\mathrm{III}) .{ }^{13-15}$ During the last decade, bis(dipyrrinato)zinc(II) complexes, as an underrepresented class of compounds, have received increasing attention as fluorophores (see Figure 1 for an overview of investigated bis(dipyrrinato)zinc(II) complexes). ${ }^{13}$ 16-22 Unfortunately, the fluorescence quantum yields $\left(\Phi_{\mathrm{F}}\right)$ of these compounds reported so far remain inferior to the structurally related BODIPY derivatives. Therefore, current recent efforts are made towards improving the luminescent properties of bis(dipyrrinato)zinc(II) complexes. It was previously demonstrated that the steric hindrance of the peripheral aryl group of the 
dipyrrinato scaffold with methyl groups transformed the compounds from a weak emitter to a strong fluorescent chromophore. ${ }^{16}$ Further studies confirmed this observation with the introduction of peripheral 1- and 2-naphthyl groups. ${ }^{20}$ Despite current research efforts, the quenching of the excited state of this class of compounds in polar solvents remains a serious problem, limiting their biological applications. This quenching effect was proposed to be caused by the formation of a non-emissive symmetry-breaking charge transfer state from the emissive excited state, which is not formed in non-polar solvents (Figure 2). ${ }^{13}, 17$ Details on the mechanism and the influence of the solvent polarity have been previously published. ${ }^{17}$ 


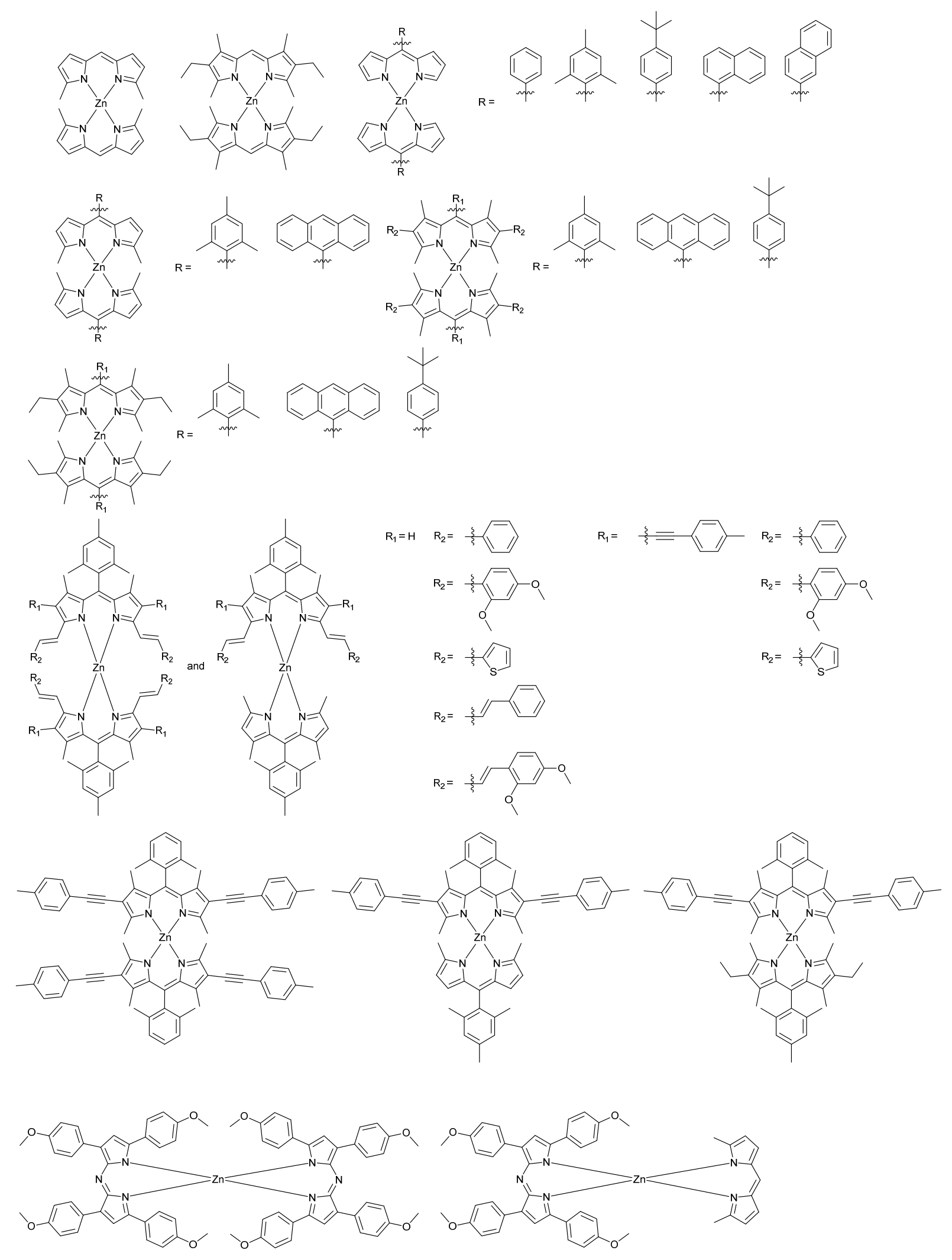

Figure 1. Overview of reported bis(dipyrrinato)zinc(II) complexes. ${ }^{13,16-22}$ 


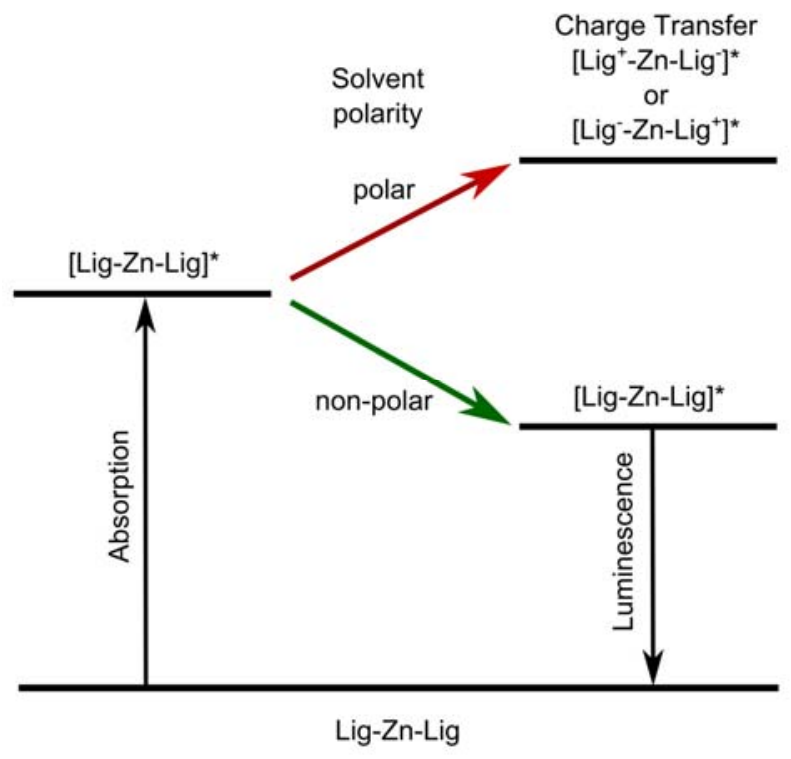

Figure 2. Simplified Jablonski diagram demonstrating the solvent dependency of bis(dipyrrinato)zinc(II) complexes. ${ }^{13,17}$

Keeping this in mind, we have designed homoleptic bis(dipyrrinato)zinc(II) complexes with different aryl groups in position 8 of the dipyrrin scaffold. Herein, we present the synthesis, in-depth photophysical and biological investigation of a series of homoleptic bis(dipyrrinato)zinc(II) complexes 1-4 (Figure 3) as imaging agents. Complexes 3 and 4 were previously reported in a study describing the photophysical properties of bis(dipyrrinato)zinc(II) complexes. ${ }^{17,} 22$ In this work, the ability of these compounds to be used as imaging probes is investigated. The compounds were found to selectively accumulate in the cytoplasm, while being taken up through passive diffusion. These complexes are highly fluorescent in toluene but undergo quenching in a polar environment. To overcome this limitation as well as their poor water solubility, the quenching effects of the excited state in water and to make the compounds selective for cancerous cells, the lead compound of this study, namely complex $\mathbf{3}$, was encapsulated inside a polymeric matrix with a biotin end group to form nanoparticles (3-NP). Biotin is a compound of the vitamin B family, which is majorly internalised by the sodium 
dependent multivitamin transporter (SMVT). Since this receptor is overexpressed in various cancers and the demand for biotin in rapidly growing tumours is higher than in normal tissue, the conjugation of an active molecule to biotin offers the possibility for specific cancer cell targeting. ${ }^{23-25}$ The nanoformulated complex was found to be highly water soluble and fluorescent. The particles selectively accumulated in the lysosomes as shown by the bright fluorescence signal observed in this organelle as well as being highly luminescent in 3D multicellular tumour spheroids (MCTS). Importantly, the particles benefit from the biotin targeting as demonstrated by a selective accumulation in transfected cancerous cells in comparison to non-transfected non-cancerous human lung cells. To the best of our knowledge, this is the first report of bis(dipyrrinato)zinc(II) complexes, which are highly fluorescent in an aqueous environment and which are selective for cancer cells.
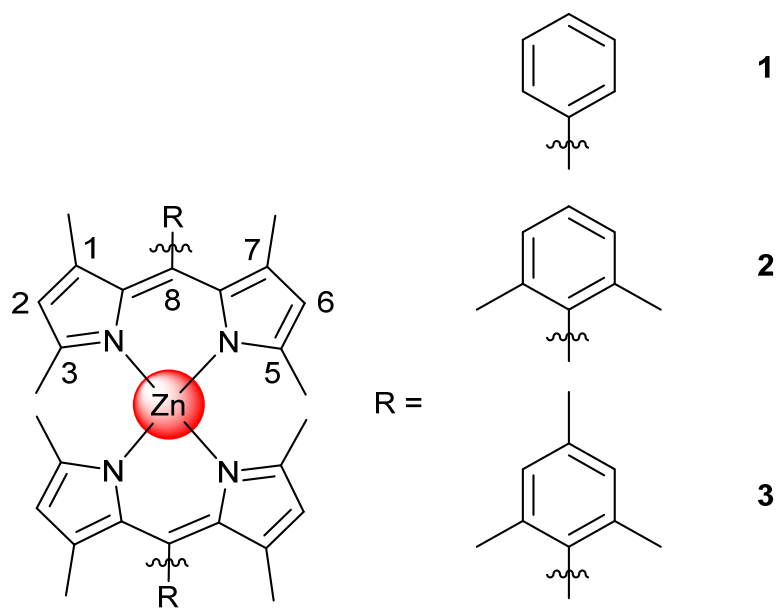<smiles>Cc1cccc(C)c1C(C)(C)C</smiles>

2<smiles>[R]=Cc1c2ccccc2cc2cc(C(C)(C)C)c(C)c(C)c12</smiles>

Figure 3. Chemical structures of the bis(dipyrrinato)zinc(II) complexes investigated in this work. 


\section{Instrumentation and Methods}

${ }^{1} \mathrm{H}$ - and ${ }^{13} \mathrm{C}-\mathrm{NMR}$ spectra were recorded on a $400 \mathrm{MHz}$ NMR spectrometer (Bruker). Chemical shifts $(\delta)$ are reported in parts per million (ppm) referenced to tetramethylsilane $(\delta 0.00)$ ppm using the residual proton solvent peaks as internal standards. Coupling constants $(\mathrm{J})$ are reported in Hertz $(\mathrm{Hz})$ and the multiplicity is abbreviated, as follows: s (singlet), $\mathrm{d}$ (doublet), and $\mathrm{m}$ (multiplet). Electrospray Ionization-Mass Spectrometry (ESI-MS) experiments were carried out using a LTQ-Orbitrap XL from Thermo Scientific (Thermo Fisher Scientific) and operated in positive ionization mode, with a spray voltage at $3.6 \mathrm{kV}$. No sheath and auxiliary gas was used. Applied voltages were 40 and $100 \mathrm{~V}$ for the ion transfer capillary and the tube lens, respectively. The ion transfer capillary was held at $275{ }^{\circ} \mathrm{C}$. Detection was achieved in the Orbitrap with a resolution set to 100,000 (at m/z 400) and an m/z range between 150 and 2000 in profile mode. Spectrum was analyzed using the acquisition software XCalibur 2.1 (Thermo Fisher Scientific). The automatic gain control (AGC) allowed for the accumulation of up to 2 * $10^{5}$ ions for Fourier Transform Mass Spectrometry (FTMS) scans, maximum injection time was set to $300 \mathrm{~ms}$ and $1 \mu$ s scan was acquired. $10 \mu \mathrm{L}$ was injected using a Thermo Finnigan Surveyor HPLC system (Thermo Fisher Scientific) with a continuous infusion of methanol at $100 \mu \mathrm{L} \cdot \min -1$. Elemental microanalyses were performed on a Thermo Flash 2000 elemental analyzer.

\section{Materials}

All of the chemicals were obtained from commercial sources and were used without further purification. Dulbecco's Modified Eagles Medium (DMEM), Dulbecco's Modified Eagles Medium supplemented with nutrient mixture F-12 (DMEM/F-12), Fetal Bovine Serum (FBS), Gibco Penicillin-Streptomycin-Glutamine (Penstrep), Dulbecco's Phosphate-Buffered Saline (PBS) were purchased from Fisher Scientific and Resazurin from ACROS Organics. 


\section{Synthesis}

General synthetic procedure for the synthesis of the dipyrrin ligand:

The aldehyde (2 mmol) and 2, 4-dimethylmethylpyrrole $(5 \mathrm{mmol})$ were dissolved in a dichloromethane solution $(40 \mathrm{~mL})$. Trifluoroacetic acid $(100 \mu \mathrm{L})$ was added and the mixture stirred at room temperature overnight under nitrogen atmosphere. Tetrachlor- $p$-benzochinon (2 mmol) was added and the reaction mixture stirred another $2 \mathrm{~h}$. After this time, the solution was filtered and the solvent evaporated. The crude product was purified by column chromatography on neutral alumina with a gradient of dichloromethane/hexane. The fractions containing the product were united and the solvent was removed. The solid was washed with $\mathrm{Et}_{2} \mathrm{O}$ and dried. Yield: $50-70 \%$.

General synthetic procedure for the complexation with Zn:

The dipyrrin ligand $(1 \mathrm{mmol})$ was dissolved in a 3:2:3 butanol/ethanol/ $\mathrm{H}_{2} \mathrm{O}(200 \mathrm{~mL})$ mixture to which $\mathrm{Zn}(\mathrm{OAc})_{2} * 2 \mathrm{H}_{2} \mathrm{O}(0.4 \mathrm{mmol})$ and $\mathrm{Et}_{3} \mathrm{~N}(4 \mathrm{mmol})$ was added. The reaction mixture was heated at reflux overnight under nitrogen atmosphere. After completion of the reaction, the solvent was removed. The crude product was purified by column chromatography on silica with a gradient of dichloromethane/pentane. The fractions containing the product were united and the solvent was removed. The solid was washed with $\mathrm{Et}_{2} \mathrm{O}$ and dried. Yield: $45-63 \%$.

$\operatorname{Bis}((Z)-2-((3,5-d i m e t h y l-2 H$-pyrrol-2-ylidene)(phenyl)methyl)-3,5-dimethyl-1Hpyrrole)zinc(II) 1: ${ }^{1} \mathrm{H}-\mathrm{NMR}\left(\mathrm{CD}_{2} \mathrm{Cl}_{2}, 400 \mathrm{MHz}\right)$ : 7.45-7.43 (m, 3H), 7.29-7.27 (m, 2H), 5.92 (s, 2H), 2.34 (s, 6H), 1.29 (s, 6H). ${ }^{13} \mathrm{C}-\mathrm{NMR}\left(\mathrm{CD}_{2} \mathrm{Cl}_{2}, 100 \mathrm{MHz}\right): 155.8,144.3,142.9,137.6$, 133.9, 127.2, 127.1, 126.8, 121.1, 16.1, 15.2. ESI-HRMS (pos. detection mode): calcd for C38H38N4Zn $[\mathrm{M}+\mathrm{H}]^{+} \mathrm{m} / \mathrm{z}$ 615.2461; found: 615.2545. Elemental analysis calcd for C38H38N4Zn (\%): C 74.08, H 6.22, N 9.09; found: C 74.12, H 6.33, N 8.89. 
Bis((Z)-2-((3,5-dimethyl-2H-pyrrol-2-ylidene)(2,6-dimethylphenyl)methyl)-3,5-dimethyl-1Hpyrrole)zinc(II) 2: ${ }^{1} \mathrm{H}-\mathrm{NMR}\left(\mathrm{CD}_{2} \mathrm{Cl}_{2}, 400 \mathrm{MHz}\right): 7.21\left(\mathrm{dd},{ }^{3} J=7.5,7.5 \mathrm{~Hz}, 1 \mathrm{H}\right), 7.12\left(\mathrm{~d},{ }^{3} J=\right.$ $7.5 \mathrm{~Hz}, 2 \mathrm{H}), 5.92(\mathrm{~s}, 2 \mathrm{H}), 2.14(\mathrm{~s}, 6 \mathrm{H}), 2.01(\mathrm{~s}, 6 \mathrm{H}), 1.26(\mathrm{~s}, 6 \mathrm{H}) .{ }^{13} \mathrm{C}-\mathrm{NMR}\left(\mathrm{CD}_{2} \mathrm{Cl}_{2}, 100 \mathrm{MHz}\right)$ : 156.4 143.7, 143.5, 139.6, 136.3, 134.6, 128.4, 128.3, 120.2, 19.5, 16.2, 14.8. ESI-HRMS (pos. detection mode): calcd for $\mathrm{C} 42 \mathrm{H} 46 \mathrm{~N} 4 \mathrm{Zn}[\mathrm{M}+\mathrm{H}]^{+} \mathrm{m} / \mathrm{z}$ 671.3087; found: 671.3079. Elemental analysis calcd for C42H46N4Zn (\%): C 75.04, H 6.90, N 8.33; found: C 74.83, H 6.94, N 8.42.

$\operatorname{Bis}((Z)-2-((3,5-d i m e t h y l-2 H$-pyrrol-2-ylidene)(mesityl)methyl)-3,5-dimethyl-1H-

pyrrole)zinc(II) 3: ${ }^{1} \mathrm{H}-\mathrm{NMR}\left(\mathrm{CD}_{2} \mathrm{Cl}_{2}, 400 \mathrm{MHz}\right): 6.95$ (s, 2H), 5.92 (s, 2H), 2.34 (s, 3H), 2.10 (s, 6H), $2.01(\mathrm{~s}, 6 \mathrm{H}), 1.29(\mathrm{~s}, 6 \mathrm{H}) \cdot{ }^{13} \mathrm{C}-\mathrm{NMR}\left(\mathrm{CD}_{2} \mathrm{Cl}_{2}, 100 \mathrm{MHz}\right):$ 156.3, 144.1, 143.6, 137.9, 136.7, 135.9, 134.9, 129.1, 120.0, 21.3, 19.4, 16.2, 14.9. ESI-HRMS (pos. detection mode): calcd for C44H51N4Zn [M+H] $]^{+} \mathrm{m} / \mathrm{z}$ 699.3400; found: 699.3402. Elemental analysis calcd for C44H50N4Zn*0.05 H2O (\%): C 75.37, H 7.20, N 7.99; found: C 74.91, H 6.97, N 8.48.

$\operatorname{Bis}((Z)-2-((3,5-d i m e t h y l-2 H$-pyrrol-2-ylidene)(anthracenyl)methyl)-3,5-dimethyl-1Hpyrrole)zinc(II) 4: ${ }^{1} \mathrm{H}-\mathrm{NMR}\left(\mathrm{CD}_{2} \mathrm{Cl}_{2}, 400 \mathrm{MHz}\right): 8.61(\mathrm{~s}, 1 \mathrm{H}), 8.07\left(\mathrm{~d},{ }^{3} \mathrm{~J}=8.5 \mathrm{~Hz}, 2 \mathrm{H}\right), 7.98$ $\left(\mathrm{d},{ }^{3} J=8.5 \mathrm{~Hz}, 2 \mathrm{H}\right), 7.51-7.48(\mathrm{~m}, 2 \mathrm{H}), 7.44-7.40(\mathrm{~m}, 2 \mathrm{H}), 5.91(\mathrm{~s}, 2 \mathrm{H}), 2.31(\mathrm{~s}, 6 \mathrm{H}), 0.45(\mathrm{~s}$, 6H). ${ }^{13} \mathrm{C}-\mathrm{NMR}\left(\mathrm{CD}_{2} \mathrm{Cl}_{2}, 100 \mathrm{MHz}\right): 157.3,144.1,141.2,136.9,134.4,132.1,131.3,128.6$, 127.7, 126.7, 125.8, 120.7, 16.7, 15.0. ESI-HRMS (pos. detection mode): calcd for C54H47N4Zn $[\mathrm{M}+\mathrm{H}]^{+} \mathrm{m} / \mathrm{z}$ 815.3087; found: 815.3089. Elemental analysis calcd for C54H46N4Zn (\%): C 79.45, H 5.68, N 6.86; found: C 79.60, H 5.73, N 6.72.

\section{X-ray crystallography}

X-ray single-crystal data were collected at 160(1) K on Rigaku OD diffractometers with an Oxford liquid-nitrogen Cryostream cooler: a XtaLAB Synergy Dualflex (Pilatus 200K detector) 
diffractometer for dipyrrin_1, 2 and 4, and a Xcalibur (CCD Ruby detector) diffractometer for 3. A single wavelength X-ray source from a micro-focus sealed X-ray tube were used with the $\mathrm{Cu} \mathrm{K} \mathrm{K}_{\alpha}$ radiation $(\lambda=1.54184 \AA)^{26}$ for the analyses of dipyrrin_1 and $\mathbf{4}$, and with the Mo $\mathrm{K}_{\alpha}$ radiation $(\lambda=0.71073 \AA)^{26}$ for the analysis of $\mathbf{2}$ and $\mathbf{3}$. The selected single crystals were mounted using polybutene oil on a loop fixed on a goniometer head and transferred to the diffractometer. Pre-experiments, data collections, data reductions and analytical absorption corrections ${ }^{27}$ were performed with the program suite CrysAlisPro. ${ }^{28}$ Using Olex $2,{ }^{29}$ the structures were solved with the SHELXT ${ }^{30}$ small molecule structure solution program and refined with the SHELXL2018/3 program package ${ }^{31}$ by full-matrix least-squares minimization on $\mathrm{F}^{2}$. Molecular graphics were created using Mercury 4.0. ${ }^{32}$ The crystal data collections and structure refinement parameters are summarized in Tabs S1 and S2. CCDC 1937531 (for 3), CCDC 1937532 (for dipyrrin_1), CCDC 1937533 (for 2) and CCDC 1937534 (for 4) contain the supplementary crystallographic data for these compounds, and can be obtained free of charge from the Cambridge Crystallographic Data Centre via www.ccdc.cam.ac.uk/data_request/cif.

\section{Spectroscopic measurements}

The absorption of the samples was recorded on a Lambda $850 \mathrm{UV} / \mathrm{VIS}$ spectrometer (PerkinElmer) at room temperature. Emission spectra were recorded on a LS 55 fluorescence spectrometer (PerkinElmer) at room temperature. For the determination of the luminescence quantum yield, the samples were prepared in Toluene solution with an absorbance of 0.1 at 500 nm. The luminescence quantum yields were calculated by comparison with the reference Rhodamine B in Ethanol $\left(\Phi_{\mathrm{em}}=0.5\right)^{33}$ applying the following formula:

$$
\begin{gathered}
\Phi_{\text {em,sample }}=\Phi_{\text {em,reference }} * \frac{F_{\text {reference }}}{\mathrm{F}_{\text {sample }}} * \frac{\mathrm{I}_{\text {sample }}}{\mathrm{I}_{\text {reference }}} *\left(\frac{\mathrm{n}_{\text {sample }}}{\mathrm{n}_{\text {reference }}}\right)^{2} \\
\mathrm{~F}=1-10^{-A}
\end{gathered}
$$


$\Phi_{\mathrm{em}}=$ luminescence quantum yield, $\mathrm{F}=$ fraction of light absorbed, $\mathrm{I}=$ integrated emission intensities, $\mathrm{n}=$ refractive index, $\mathrm{A}=$ absorbance of the sample at irradiation wavelength

\section{Stability in toluene/ $\mathrm{H}_{2} \mathrm{O} / \mathrm{DMEM}$}

The stability of the complex in Toluene $/ \mathrm{H}_{2} \mathrm{O} / \mathrm{DMEM}(2 \%$ DMSO, $v \%)$ was investigated by UV/Vis spectroscopy. The complex was dissolved with about 0.5 absorption at its absorption maximum and stored at room temperature in the dark. The absorption spectrum from 210-700 nm was recorded with a SpectraMax M2 Microplate Reader (Molecular Devices) after each time interval $(0,1,2,4,8,12,24,48 \mathrm{~h})$ and compared.

\section{Photostability}

The photostability of the complex in Toluene $(2 \%$ DMSO, $v \%)$ was investigated by UV/Vis spectroscopy. The complex was dissolved with about 0.5 absorption at its absorption maximum and exposed to a constant LED irradiation $510 \mathrm{~nm}\left(4.2 \mathrm{~mW} / \mathrm{cm}^{2}\right)$ with an Atlas Photonics LUMOS BIO irradiator. The absorption spectrum from 210-700 $\mathrm{nm}$ was recorded with a SpectraMax M2 Microplate Reader (Molecular Devices) after each time interval (0, 5, 10, 15, 20, 25, $30 \mathrm{~min}$ ) and compared.

\section{Distribution coefficient}

The lipophilicity of a compound was determined by measuring its distribution coefficient between the PBS and Octanol phase by using the "shake-flask" method. For this technique, the used phases were previously saturated in each other. The compound was dissolved in the phase (A) with its major presence with an absorbance of about 0.5 at $500 \mathrm{~nm}$. This solution was then mixed with an equal volume of the other phase (B) at $80 \mathrm{rpm}$ for $8 \mathrm{~h}$ with an Invitrogen sample mixer and then equilibrated overnight. The phase A was then carefully separated from phase B. 
The amount of the compound before and after the sample mixing was determined by UV/Vis spectroscopy at $500 \mathrm{~nm}$ using a SpectraMax M2 Microplate Reader (Molecular Devices). The evaluation of the complexes was repeated three times and the ratio between the organic and aqueous phase calculated.

\section{Cell culture}

Human cervical carcinoma (HeLa), adenocarcinomic human alveolar basal epithelial cells (A549) human lung fibroblasts (HLF) cells were cultured using DMEM media and retinal pigment epithelium (RPE-1) cells using DMEM/F-12 with addition of $10 \%$ FBS and 1\% penstrep. The cells were cultivated and maintained at $37{ }^{\circ} \mathrm{C}$ in a cell culture incubator at $37{ }^{\circ} \mathrm{C}$ with $5 \% \mathrm{CO}_{2}$ atmosphere. Before an experiment, the cells were passaged three times.

\section{Cellular uptake}

The cellular uptake of the complex was investigated by the determination of the $\mathrm{Zn}$ content inside the cells. The complex with a final concentration of $25 \mu \mathrm{M}(2 \% \mathrm{DMSO}, \nu \%)$ was incubated at $37^{\circ} \mathrm{C}$ on a cell culture dish with a density of ca. 4-6 $10^{6}$ cells in $10 \mathrm{~mL}$ of media. After this time, the media was removed and the cells washed with cell media. The cells were trypsinised, harvested, centrifuged and resuspended. The number of cells on each dish was accurately counted. Each sample was the digested using a $60 \% \mathrm{HNO}_{3}$ solution for three days. Each sample was diluted to solution of $2 \% \mathrm{HNO}_{3}$ in water. The $\mathrm{Zn}$ content was determined using an ICP-MS apparatus and comparing the results with the $\mathrm{Zn}$ references. The $\mathrm{Zn}$ content was then associated with the number of cells.

\section{Cellular uptake mechanism}


The mechanism of the cellular uptake was investigated by systematic inhibition of different uptake pathways and afterwards determination of the amount of $\mathrm{Zn}$ inside the cells via ICPMS. For the experiment, $1 \cdot 10^{6}$ cells were pretreated with the corresponding inhibitor.

Control: The cells were incubated with the complex $(25 \mu \mathrm{M}, 2 \%$ DMSO, $v \%)$ for $1 \mathrm{~h}$ at $37^{\circ} \mathrm{C}$. After this time, the cells were washed with PBS. The cells were detached with trypsin, harvested, centrifuged and resuspended. The number of cells on each dish was accurately counted. Each sample was the digested using a $60 \% \mathrm{HNO}_{3}$ solution for three days. Each sample was diluted to solution of $2 \% \mathrm{HNO}_{3}$ in water. The $\mathrm{Zn}$ content was determined using an ICPMS apparatus and comparing the results with the $\mathrm{Zn}$ references. The $\mathrm{Zn}$ content was then associated with the number of cells.

Low temperature: The cells were incubated at $4^{\circ} \mathrm{C}$ for $1 \mathrm{~h}$. The cells were further incubated with the complex $(25 \mu \mathrm{M}, 2 \% \mathrm{DMSO}, v \%)$ for $1 \mathrm{~h}$ at $4{ }^{\circ} \mathrm{C}$. After this time, the cells were washed with PBS. The cells were detached with trypsin, harvested, centrifuged and resuspended. The number of cells on each dish was accurately counted. Each sample was the digested using a $60 \% \mathrm{HNO}_{3}$ solution for three days. Each sample was diluted to solution of $2 \% \mathrm{HNO}_{3}$ in water. The $\mathrm{Zn}$ content was determined using an ICP-MS apparatus and comparing the results with the $\mathrm{Zn}$ references. The $\mathrm{Zn}$ content was then associated with the number of cells.

Metabolic Inhibition: The cells were incubated with 2-Deoxy- $D$-glucose $(50 \mathrm{mM})$ and oligomycin $(5 \mu \mathrm{M})$ for $1 \mathrm{~h}$. After the preincubation, the cells were washed with PBS and further incubated with the complex $(25 \mu \mathrm{M}, 2 \%$ DMSO, $v \%)$ for $1 \mathrm{~h}$ at $37^{\circ} \mathrm{C}$. After this time, the cells were washed with PBS. The cells were detached with trypsin, harvested, centrifuged and resuspended. The number of cells on each dish was accurately counted. Each sample was the 
digested using a $60 \% \mathrm{HNO}_{3}$ solution for three days. Each sample was diluted to solution of $2 \%$ $\mathrm{HNO}_{3}$ in water. The $\mathrm{Zn}$ content was determined using an ICP-MS apparatus and comparing the results with the $\mathrm{Zn}$ references. The $\mathrm{Zn}$ content was then associated with the number of cells.

Endocytic inhibition: The cells were incubated with $\mathrm{NH}_{4} \mathrm{Cl}(50 \mathrm{mM})$ or chloroquine $(100 \mu \mathrm{M})$ for $1 \mathrm{~h}$. After the preincubation, the cells were washed with PBS and further incubated with the complex $(25 \mu \mathrm{M}, 2 \% \mathrm{DMSO}, v \%)$ for $1 \mathrm{~h}$ at $37^{\circ} \mathrm{C}$. After this time, the cells were washed with PBS. The cells were detached with trypsin, harvested, centrifuged and resuspended. The number of cells on each dish was accurately counted. Each sample was the digested using a $60 \% \mathrm{HNO}_{3}$ solution for three days. Each sample was diluted to solution of $2 \% \mathrm{HNO}_{3}$ in water. The $\mathrm{Zn}$ content was determined using an ICP-MS apparatus and comparing the results with the $\mathrm{Zn}$ references. The $\mathrm{Zn}$ content was then associated with the number of cells.

Cation transporter inhibition: The cells were incubated with tetraethylammonium chloride (1 $\mathrm{mM}$ ) for $1 \mathrm{~h}$. After the preincubation, the cells were washed with PBS and further incubated with the complex $(25 \mu \mathrm{M}, 2 \% \mathrm{DMSO}, v \%)$ for $1 \mathrm{~h}$ at $37^{\circ} \mathrm{C}$. After this time, the cells were washed with PBS. The cells were detached with trypsin, harvested, centrifuged and resuspended. The number of cells on each dish was accurately counted. Each sample was the digested using a $60 \% \mathrm{HNO}_{3}$ solution for three days. Each sample was diluted to solution of $2 \%$ $\mathrm{HNO}_{3}$ in water. The $\mathrm{Zn}$ content was determined using an ICP-MS apparatus and comparing the results with the $\mathrm{Zn}$ references. The $\mathrm{Zn}$ content was then associated with the number of cells.

Sodium-dependent multivitamin transporter inhibition: The cells were incubated with pantothenic acid $(50 \mu \mathrm{M})$ or lipoic acid $(50 \mu \mathrm{M})$ for $1 \mathrm{~h}$. After the preincubation, the cells were washed with PBS and further incubated with the complex $(25 \mu \mathrm{M}, 2 \% \mathrm{DMSO}, v \%)$ for $1 \mathrm{~h}$ at 
$37^{\circ} \mathrm{C}$. After this time, the cells were washed with PBS. The cells were detached with trypsin, harvested, centrifuged and resuspended. The number of cells on each dish was accurately counted. Each sample was the digested using a $60 \% \mathrm{HNO}_{3}$ solution for three days. Each sample was diluted to solution of $2 \% \mathrm{HNO}_{3}$ in water. The $\mathrm{Zn}$ content was determined using an ICPMS apparatus and comparing the results with the $\mathrm{Zn}$ references. The $\mathrm{Zn}$ content was then associated with the number of cells.

\section{Intracellular distribution by confocal luminescence imaging}

The co-localisation of the complex was determined under usage of its luminescence properties. $1 \cdot 10^{4}$ cells were seeded on $35 \mathrm{~mm}$ confocal dishes and allowed to adhere overnight. The cells were incubated with the complex $(50 \mu \mathrm{M}, 2 \% \mathrm{DMSO}, v \%)$ for $4 \mathrm{~h}$ at $37^{\circ} \mathrm{C}$ in the dark. After this time, the cells were washed with PBS. The cells were further incubated with Hoechst 33342 (5 $\mu \mathrm{g} / \mathrm{mL})$, LysoTracker Deep Red (500 nM) and MitoTracker Deep Red (500 nM) for 30 min at $37^{\circ} \mathrm{C}$ in the dark. The cells were washed three times with PBS. Confocal images were taken with a LSM 880 (Carl Zeiss) laser scanning confocal microscope equipped with a GaAsP detector. The organelle trackers Hoechst $33342\left(\lambda_{\mathrm{ex}}=405 \mathrm{~nm}, \lambda_{\mathrm{em}}=410-470 \mathrm{~nm}\right)$, MitoTracker Deep Red $\left(\lambda_{\mathrm{ex}}=633 \mathrm{~nm}, \lambda_{\mathrm{em}}=650-720 \mathrm{~nm}\right)$ and LysoTracker Deep Red $\left(\lambda_{\mathrm{ex}}=\right.$ $633 \mathrm{~nm}, \lambda_{\mathrm{em}}=650-720 \mathrm{~nm}$ ) were excited and detected as recommended by the supplier. The investigated $\mathrm{Zn}$ complexes were detected under usage of their luminescence properties $\left(\lambda_{\mathrm{ex}}=\right.$ $\left.514 \mathrm{~nm}, \lambda_{\mathrm{em}}=530-610 \mathrm{~nm}\right)$.

\section{Intracellular distribution by ICP-MS}

The co-localisation of the complex was determined by measuring the $\mathrm{Zn}$ content inside the cell via ICP-MS. $10 \cdot 10^{6}$ cells were incubated with the complex $(25 \mu \mathrm{M}, 2 \% \mathrm{DMSO}, v \%)$ for $4 \mathrm{~h}$ at $37^{\circ} \mathrm{C}$ in the dark. After this time, the cells were detached with trypsin and harvested. The 
number of cells was accurately counted. The amount was equally divided into four portions. In the first portion, the nucleus was extracted using a nucleus extraction kit (Sangon Biotech) following manufacturer recommended protocol; in the second portion, the mitochondria was extracted using a mitochondria extraction kit (Sangon Biotech) following the manufacturer recommended protocol and in the third portion, the lysosome was extracted using a lysosome extraction kit (GenMed Scientific) following manufacturer recommended protocol. Using the fourth portion, the cytoplasm was extracted. For this, the cells were detached with trypsin, harvested and centrifuged. The cell pellet was resuspended in lysis buffer and the cells were lysed. The cell organelles were separated using a vacuum ultracentrifuge (Optima MAX-XP ultracentrifuge, Beckman Coulter) for $150 \mathrm{~min}$ at $200000 \mathrm{~g}$ at $4{ }^{\circ} \mathrm{C}$. The supernatant solution was separated. Each sample was the digested using a $60 \% \mathrm{HNO}_{3}$ solution for three days and was diluted to a solution of $2 \% \mathrm{HNO}_{3}$ in water. The $\mathrm{Zn}$ content was determined using an ICPMS apparatus and comparing the results with the $\mathrm{Zn}$ references. The $\mathrm{Zn}$ content was then associated with the number of cells.

\section{(Photo-)cytotoxicity on 2D cell monolayers}

The cytotoxicity of the complexs was assessed by measuring cell viability using a fluorometric resazurin assay. The cultivated cells were seeded in triplicates in 96 well plates with a density of 4000 cells per well in $100 \mu \mathrm{L}$ of media. After $24 \mathrm{~h}$, the medium was removed and the cells were treated with increasing concentrations of the complex diluted in cell media achieving a total volume of $200 \mu \mathrm{L}$. The cells were incubated with the complex for $4 \mathrm{~h}$. After this time, the media was removed and replaced with $200 \mu \mathrm{L}$ of fresh medium. For the phototoxicity studies, the cells were exposed to light with an Atlas Photonics LUMOS BIO irradiator. Each well was constantly illuminated with either a $510 \mathrm{~nm}$ or $540 \mathrm{~nm}$ irradiation. During this time, the temperature was maintained constantly at $37{ }^{\circ} \mathrm{C}$. The cells were grown in the incubator for 
additional $44 \mathrm{~h}$. For the determination of the dark cytotoxicity, the cells were not irradiated and after the medium exchange directly incubated for $44 \mathrm{~h}$. After this time, the medium was replaced with fresh medium containing resazurin with a final concentration of $0.2 \mathrm{mg} / \mathrm{mL}$. After $4 \mathrm{~h}$ incubation, the amount of the fluorescent product resorufin was determined upon excitation at $540 \mathrm{~nm}$ and measurement its emission at $590 \mathrm{~nm}$ using a SpectraMax M2 Microplate Reader (Molecular Devices). The obtained data was analyzed with the GraphPad Prism software.

\section{Generation and analysis of 3D multicellular tumor spheroids (MCTS)}

A suspension of $0.75 \%$ agarose in PBS buffer was heated inside a high-pressure autoclave. The hot emulsion was transferred into wells $(50 \mu \mathrm{L}$ per well) of a 96 cell culture well plate. The plates were exposed for $3 \mathrm{~h}$ to UV irradiation to ensure the sterility and allow the agarose solution to cool down. After this time, the agarose was overlayed with a HeLa cell suspension at a density of 3000 cells per well in $150 \mu \mathrm{L}$ of media. The MCTS were cultivated and maintained at $37{ }^{\circ} \mathrm{C}$ in a cell culture incubator at $37{ }^{\circ} \mathrm{C}$ with $5 \% \mathrm{CO}_{2}$ atmosphere. The culture media was replaced every two days. Within two-three days MCTs were formed from the cell suspension. The formation as well as integrity and diameter of the MCTs was monitored by an Axio Observer Z1 (Carl Zeiss) phase contrast microscope. The luminescence images along the z-axis were captured by $\left(\lambda_{\mathrm{ex}}=514 \mathrm{~nm}, \lambda_{\mathrm{em}}=530-610 \mathrm{~nm}\right)$ excitation in the z-stack mode with a an LSM 880 (Carl Zeiss) laser scanning confocal microscope equipped with a GaAsP detector.

\section{Preparation of particles}

A solution of $3 \mathrm{mg}$ of $\mathbf{3}$ in $0.5 \mathrm{~mL}$ DCM was added to a solution of $6 \mathrm{mg}$ of 1,2-distearoyl-snglycero-3-phosphoethanolamine-N-[biotin(polyethylene glycol)-2000] ammonium salt (DSPE-PEG 2000 -biotin) in $19.5 \mathrm{~mL} \mathrm{H}_{2} \mathrm{O}$. The solution was further treated with ultrasonic pulses with a Scientz - II D ultrasonic homogenizer using a 2 x 10 min method ( $\mathrm{t}_{\text {sonication }}=2 \mathrm{~s}$, Power 
$=15 \%$, tbreak $=1 \mathrm{~s}$ ) while keeping the sample constantly at $25^{\circ} \mathrm{C}$. After this, the DCM was removed by evaporation at $50{ }^{\circ} \mathrm{C}$. The mixture was filtered through a $0.2 \mu \mathrm{m}$ syringe filter to remove large aggregates. After that a clear transparent solution in $\mathrm{H}_{2} \mathrm{O}$ was obtained. The amount of encapsulated complex was determined by ICP-MS as $0.129 \mathrm{mg} / \mathrm{mL}$ (Yield: 86\%).

\section{Release kinetics of the particles}

The release kinetics of the particles were investigated by dialysis against $1 \mathrm{x}$ PBS at physiological $\mathrm{pH}(7.4)$ and low $\mathrm{pH}(5.0)$ at $37^{\circ} \mathrm{C}$. The particles $(200 \mu \mathrm{L})$ were added to into a dialysis bag and placed in the PBS bath with gentle shaking. PBS was changed every $12 \mathrm{~h}$. At various time points (1h, $2 \mathrm{~h}, 4 \mathrm{~h}, 12 \mathrm{~h}, 24 \mathrm{~h}, 48 \mathrm{~h})$ the dialysis units were removed and the amount of compound determined by ICP-MS.

\section{Selectivity assay between cancerous and non-cancerous cells}

Adenocarcinomic human alveolar basal epithelial cells (A549) were transfected with the fluorescence protein mCherry using a transfection kit (Beyotime) and following the manufacturer recommended protocol. Not successfully transfected cells were removed using the antibiotic G-418. The cells were mixed with an equal amout of non-cancerous human lung fibroblasts (HLF) cells and allowed to adhere overnight. The cells were incubated with the complex $(10 \mu \mathrm{M})$ for $4 \mathrm{~h}$ at $37^{\circ} \mathrm{C}$ in the dark. After this time, the cells were washed with PBS. Confocal images were taken with a LSM 880 (Carl Zeiss) laser scanning confocal microscope equipped with a GaAsP detector. The investigated $\mathrm{Zn}$ complexes $\left(\lambda_{\mathrm{ex}}=514 \mathrm{~nm}, \lambda_{\mathrm{em}}=530\right.$ $610 \mathrm{~nm})$ and the fluorescence protein mCherry $\left(\lambda_{\mathrm{ex}}=633 \mathrm{~nm}, \lambda_{\mathrm{em}}=650-720 \mathrm{~nm}\right)$ were detected under usage of their luminescence properties.

\section{RESULTS AND DISCUSSION}




\section{Synthesis and Characterisation of 1-4}

The dipyrrin ligands were prepared by reacting 2, 4-dimethylmethylpyrrole with the corresponding aldehydes in the presence of trifluoracetic acid. The dipyrrin scaffold was then oxidised with tetrachloro- $p$-benzoquinone. Finally, the complexes 1-4 were obtained by deprotonation of the dipyrrin ligands with $\mathrm{Et}_{3} \mathrm{~N}$ and complexation with $\mathrm{Zn}(\mathrm{OAc})_{2} \cdot 2 \mathrm{H}_{2} \mathrm{O}$. All complexes were analysed using ${ }^{1} \mathrm{H}-$ and ${ }^{13} \mathrm{C}-\mathrm{NMR}$ and HRMS (Scheme S1, Figure S1-S12). The purity of the compounds was verified by elemental analysis.

\section{X-ray crystallography}

The Zn(II) complexes 2, 3 and 4 (Table S1-S2, Figure S13-S16) were characterized with singlecrystal X-ray diffraction studies. The crystal structures of complexes $\mathbf{3}$ and $\mathbf{4}$ were previously reported by Trinh et al. ${ }^{17}$ in 2014 and Tsuchiya et al. ${ }^{22}$ in 2016, respectively. The crystal structure of 4 reported by Tsuchiya et al. was investigated at $113 \mathrm{~K}$ and exhibits a ratio of two solvent molecules of dichloromethane for one $\mathrm{Zn}(\mathrm{II})$ molecule. The crystal structure reported herein was investigated at $160 \mathrm{~K}$, presents very similar cell parameters and the same $\mathrm{C} 2 / \mathrm{c}$ space group than the previous one, but the solvent molecules of dichloromethane appeared severely disordered. The SQUEEZE routine of $P L A T O N^{34}$ was used to calculate the solvent contribution, it suggested a partial occupancy since 580 electrons were attributed to solvent molecules in the P1 cell ie. about 1.47 molecules of dichloromethane per asymmetric unit for two sets of positions. Despite that little difference, we can consider that the two crystal structures are equivalent. The crystal structure of $\mathbf{3}$ is a polymorph of the previously reported structure from Trinh et al.. The $\mathrm{Zn}(\mathrm{II})$ molecules crystallized in the monoclinic space group $\mathrm{P} 21 / \mathrm{n}$ and in the orthorhombic space group Pbca, respectively. In both structures, no solvent molecules are present. In our crystal structures, the $\mathrm{Zn}(\mathrm{II})$ complexes 2, 3 and $\mathbf{4}$ exhibit a distorted tetrahedral 
coordination with two substituted dipyrrinato molecules bound to the central $\mathrm{Zn}$ atom. The $\mathrm{Zn}$ - $\mathrm{N}$ bond distances are very similar for all complexes, they fall in the range 1.9583(10) 1.9642(10) for $2,1.9621(11)-1.9690(11) \AA$ for 3 and 1.956(4) - 1.967(3) $\AA$ for 4 . The bite angles $\mathrm{N}-\mathrm{Zn}-\mathrm{N}$ are all found in the narrow range $94.71(14)-95.35(15)^{\circ}$ while the relative orientation of the bidentate ligands is nearly perpendicular in the three structures. Based on these structural parameters, we can assume that there is no significant influence from the substituent of the dipyrrinato ligand (dimethylphenyl, trimethylphenyl and anthracene) on the coordination geometry of the metal center.

\section{Photophysical Characterisation of 1-4}

The photophysical properties (Table S3) of 1-4 were investigated to evaluate their potential as imaging probes. As expected from previous works on bis(dipyrrinato)zinc(II) complexes, ${ }^{13}, 16-19$ these compounds have a strong and sharp absorption at 493-495 $\mathrm{nm}$. The different aryl groups in position 8 of the complex did neither cause a significant blue or red shift. The maximum of the emission signal was measured to be between $505-520 \mathrm{~nm}$, resulting in an overlay between absorption and emission spectra (Figure 4a) and a small Stokes shift of 12-25 nm. As documented for various BODIPY complexes and other bis(dipyrrinato)metal complexes, ${ }^{3,13,16}$ the complexes $\mathbf{2 - 4}$, which were designed with a steric hinderance of the rotation of the aryl groups, were found to have highly increased fluorescence quantum yields $\left(\Phi_{\mathrm{F}}\right)$ in comparison to the unsubstituted, model compound 1. As the compound with the strongest fluorescence signal, $\mathbf{3}$ was identified as the lead compound of the series. Interestingly, the $\Phi_{\mathrm{F}}$ values of the compounds 1-4 vary highly based on the solvent employed during the measurements (Figure $4 \mathrm{~b}$ ). Fluorescence was found to be very intense in non-polar solvents while it was quenched in polar solvents. Recent 
investigations have demonstrated that this effect was caused by the formation of a nonemissive symmetry-breaking charge transfer state, which is only formed in polar solvents. ${ }^{17}$ Worthy of note, commercially available dyes were found to have much higher $\Phi_{F}$ values than the compounds investigated in this study while being relatively insensitive to the polarity of the solvent. ${ }^{3,4,8}$

a)

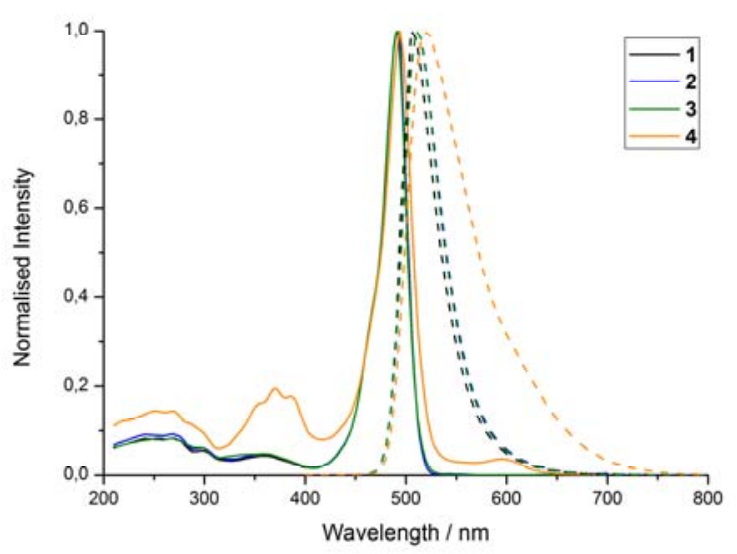

b)

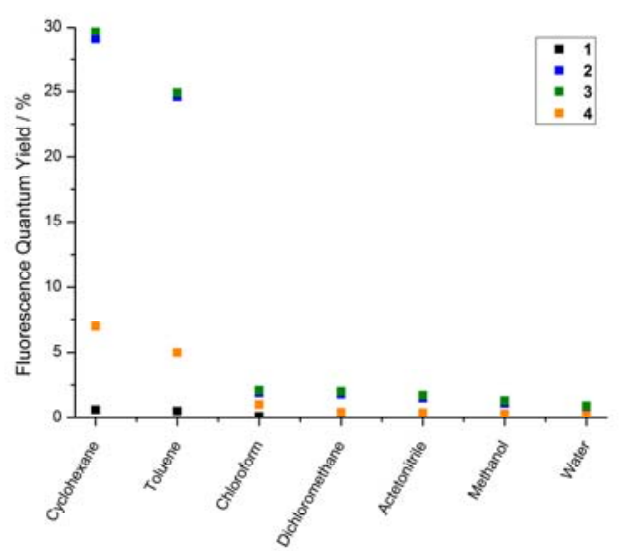

Figure 4. Spectroscopic properties of 1-4. a) Normalised absorption (solid line) and emission spectra (dashed line) in toluene. b) Fluorescence quantum yields of 1-4 plotted depending on the solvent (5\% DMSO, $v \%)$ from non-polar to polar.

\section{Stability of 1-4}

As an important parameter for an imaging agent, its stability in different solvents as well as upon light exposure was evaluated, as previous investigations showed that this could be critical for metal complexes. ${ }^{35-36}$ The complexes were incubated in toluene, water and cell culture media (DMEM) and the corresponding absorbance spectra monitored over 48 h. As no significant difference (Figure S17-S28) was detected, the stability of the complexes was confirmed. In addition, the stability in toluene upon constant LED irradiation was assessed. Only minimal changes in the absorption spectra (Figure S29S32) were recorded, demonstrating the photostability of the compounds. In comparison, 
commercially available dyes are also associated with a high chemical stability and stability upon light exposure..$^{3,4,8}$

\section{Determination of the $\log P$ values of 1-4}

The lipophilicity/hydrophilicity of the compounds was assessed by determination of the $\log P$ values between an aqueous phosphate buffer saline (PBS) phase and an octanol phase using the "shake-flask" method. ${ }^{37-38}$ All compounds were majorly present in the organic phase with $\log P$ values between $0.4-1.1$ (Table S4), indicative of their lipophilicity. This result was expected as the complexes are uncharged and bear lipophilic aromatic systems.

\section{Cellular Uptake and Uptake Mechanism of 1-4}

For further assessment, the cellular uptake of the compounds was investigated in human cervical carcinoma (HeLa) cells by measuring the amount of $\mathrm{Zn}$ inside the cells after subtracting the natural amount using inductively coupled plasma mass spectrometry (ICP-MS). Importantly, the investigations showed that all compounds were able to be internalized inside the cells. In agreement with the $\log P$ values, compound 4 was found to be able to reach a slightly higher concentration inside the cell compared to $\mathbf{1 - 3}$ after 4 $\mathrm{h}$ incubation (Figure S33). Furthermore, the internalisation mechanism of the compounds by blocking different pathways with metabolic (2-deoxy-D-glucose and oligomycin), cationic transporter (tetraethylammonium chloride) and endocytotic (ammonium chloride or chloroquine) inhibitors was investigated (Figure S35-S38). As these inhibitors had only a negligible effect on the uptake, the involvement of these pathways was excluded. The incubation at lower temperature $\left(4^{\circ} \mathrm{C}\right.$, Figure S34-S37) demonstrated a slightly lower uptake, which is caused by the temperature dependency 
of diffusion processes at a lower temperature. Overall, these results suggest an uptake by an energy-independent passive diffusion pathway for all compounds.

\section{Cellular Localisation of 1-4}

The cellular localisation was determined by confocal laser scanning microscopy in HeLa cells (Figure 5a) and comparison of the distribution pattern inside the cells with the commercial dyes MitoTracker Deep Red, LysoTracker Deep Red and Hoechst 33342. As no significant congruency was detected, it indicates that the major localisation of the complexes 1-4 was not inside these organelles. For verification, the localisation of the complexes was also investigated by extraction of the major cellular organelles (i.e., nucleus, mitochondria, lysosome, cytoplasm) and quantification of the amount of $\mathrm{Zn}$ inside using ICP-MS. In agreement with the microscopy studies, all complexes 1-4 were found to be majorly present in the cytoplasm (Figure 5b). Worthy of note, structurally related bis(dipyrrinato)zinc(II) complexes as well as related $\mathrm{Zn}$ (II) porphyrin complexes previously investigated were also found to be mainly localising unselectively in the cell or with membrane proteins. ${ }^{39-40}$ 
a)

1

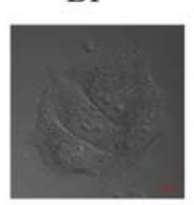

2

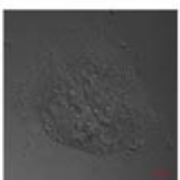

3

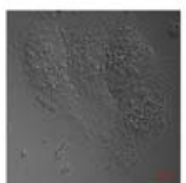

4

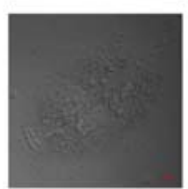

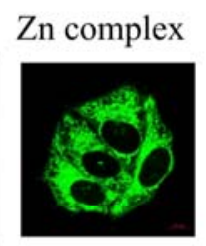
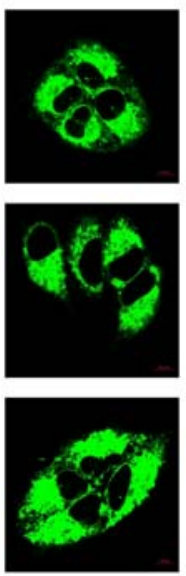
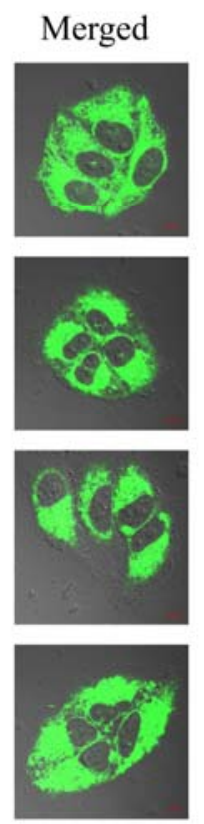

b)

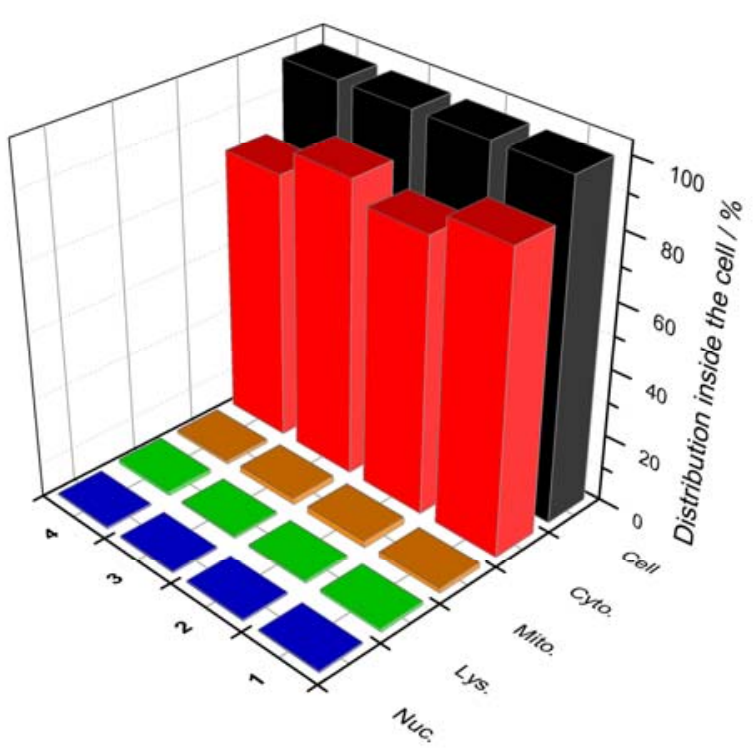

Figure 5. a) Confocal luminescence image of HeLa cells incubated with compounds 1-4 (50 $\mu \mathrm{M}, 2 \% \mathrm{DMSO}, \nu \%$ ) for $4 \mathrm{~h}$ at $37^{\circ} \mathrm{C}$ in the dark. The investigated $\mathrm{Zn}$ complexes were detected using their luminescence properties $\left(\mathrm{Zn}, \lambda_{\mathrm{ex}}=514 \mathrm{~nm}, \lambda_{\mathrm{em}}=530-610 \mathrm{~nm}\right)$. b) Sub-cellular distribution $($ Cell $=$ Whole cell, Cyto. $=$ Cytoplasm, Mito. $=$ Mitochondria, Lys. $=$ Lysosome, Nuc. $=$ Nucleus $)$ of 1-4 $(25 \mu \mathrm{M}, 2 \%$ DMSO, $v \%)$ in HeLa cells after $4 \mathrm{~h}$ incubation in the dark determined after organelle extraction and determination of the amount of $\mathrm{Zn}$ inside each organelle by ICP-MS.

\section{(Photo-)cytotoxicity of 1-4}

The cytotoxicity of the complexes in the dark as well as upon irradiation at $510 \mathrm{~nm}$ (20 $\left.\min , 5.0 \mathrm{~J} / \mathrm{cm}^{2}\right)$ and $540 \mathrm{~nm}\left(40 \mathrm{~min}, 9.5 \mathrm{~J} / \mathrm{cm}^{2}\right)$ towards non-cancerous retinal pigment epithelium (RPE-1) and human cervical carcinoma (HeLa) cells was investigated (Table S5) as it was previously shown that this could be problematic for imaging agents. ${ }^{41}$ All complexes 1-4 were found to be non-toxic in the dark as well as upon irradiation ( $\mathrm{IC}_{50}$ $>100 \mu \mathrm{M}$ ), which is an important requirement for an imaging probe as these agents should not trigger any kind of stress or toxicity for the cell. 


\section{Nanoparticle formation (3-NP) and characterisation}

Despite the success of the investigated compounds to enter HeLa cells with a green fluorescence in the cytoplasm, the abilities of bis(dipyrrinato)zinc(II) complexes to act as imaging probes is limited due to 1) the quenching of the excited state in polar solvents, 2) water solubility problems as well as 3) the lack of selectivity of the compounds for cancerous cells. To overcome these limitations, the lead compound $\mathbf{3}$ with the brightest fluorescence was encapsulated in the polymer matrix 1,2-distearoyl-sn-glycero-3phosphoethanolamine-N-[biotin(polyethylene glycol)-2000] ammonium salt (DSPEPEG2000-biotin) to generate the corresponding nanoparticle formulation 3-NP with a biotin end group as a targeting moiety. Worthy of note, PEGylated phospholipids have been approved by US Food and Drug administration (FDA) for medical applications. The generated nanoparticles 3-NP were found to be spherical shaped with an average size of $93 \mathrm{~nm}$, as determined by dynamic light scattering (DLS, Figure 6a) and $104 \mathrm{~nm}$, as determined by transmission electron microscopy (TEM, Figure 6b). Very importantly, the particles benefit from a high water solubility. The photophysical evaluation of 3-NP showed no significant difference in the absorption or emission spectra between $\mathbf{3}$ and 3NP, indicating that the photophysical properties are not being influenced by the encapsulation. The nanoparticle were found to have a $\Phi_{\mathrm{F}}$ value of 0.26 , which is in the same range than the complex alone in an apolar solvent. Overall, this encapsulation allows overcoming the quenching effects associated with bis(dipyrrinato)zinc(II) complexes. The cytotoxicity of 3-NP in the dark as well as upon irradiation at $500 \mathrm{~nm}$ (16.7 $\mathrm{min}, 10.0 \mathrm{~J} / \mathrm{cm}^{2}$ ) in HeLa cells was investigated. As expected, 3-NP was found to be non-toxic $\left(\mathrm{IC}_{50}>100 \mu \mathrm{M}\right)$, as requested for an imaging agent. The release of the complex from the nanoparticle formulation was studied by dialysis against a PBS 
solution at physiological $\mathrm{pH}$ (7.4) and lowered $\mathrm{pH}$ (5.0). As expected, the formulation remains intact at physiological $\mathrm{pH}$ whereas the complex is released at low $\mathrm{pH}$ (Figure S38).

a)

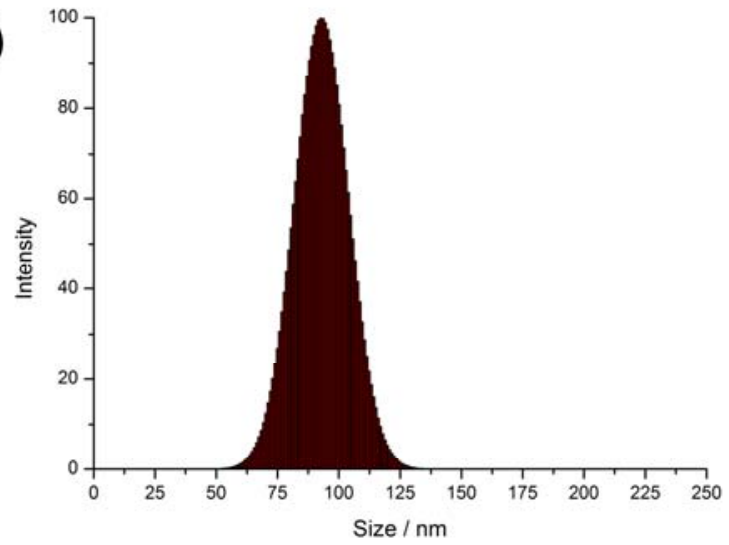

b)

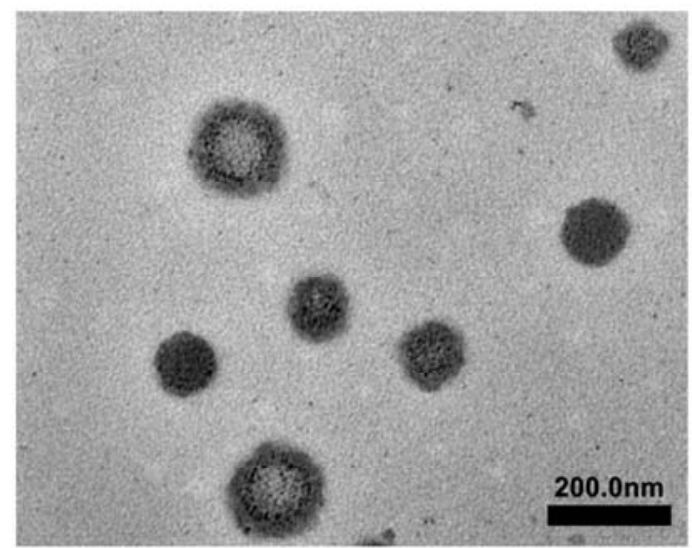

Figure 6. Characterization of 3-NP. a) Size distribution determined by DLS. b) Transmission electron microscopy (TEM) image.

\section{Cellular Uptake and Uptake Mechanism of 3-NP}

The cellular internalisation and uptake mechanism of 3-NP was investigated by blocking different pathways through preincubation with various inhibitors (Figure S39). In addition to the pathways investigated for $\mathbf{1 - 4}$, the sodium-dependent multivitamin transporter (SMVT) as a potential internalisation mechanism was studied as biotin as well as many biotin conjugates are majorly taken up through this pathway. ${ }^{42}$ As the incubation with pantothenic acid and lipoic acid drastically decreased the amount of the compound inside the cell, the uptake through SMVT was assumed to be the primary pathway. In addition, the incubation with metabolic inhibitors as well as upon lower temperature $\left(4^{\circ} \mathrm{C}\right)$ decreased the amount of the compound inside the cell, suggesting an energy-dependent mechanism. Furthermore, the incubation with endocytotic inhibitors 
also decreased the internalisation. Overall, these results suggest that $\mathbf{3 - N P}$ is majorly taken up through the SMVT transporter while minor amounts are taken up by endocytosis.

\section{Cellular Localisation of 3-NP}

The imaging properties of the particles 3-NP were further studied by determination of their localisation within HeLa cells using confocal laser scanning microscopy (Figure 7a) as well as ICP-MS after the corresponding organelle extraction (Figure 7b). Interestingly, whereas complex $\mathbf{3}$ accumulated in the cytoplasm, its nanoformulation 3NP was majorly found in the lysosomes and minorly in the surrounding cytoplasm. A recent study of the encapsulation of organic aromatic systems or structurally related bis(dipyrrinato)zinc(II) complexes with a $\mathrm{DSPE}_{-} \mathrm{PEG}_{2000}-\mathrm{OCH}_{3}$ matrix for photodynamic therapy, aggregating induced emission and 2-Photon imaging, were also found to be mainly localising in this organelle. ${ }^{43,44}$ 
a)
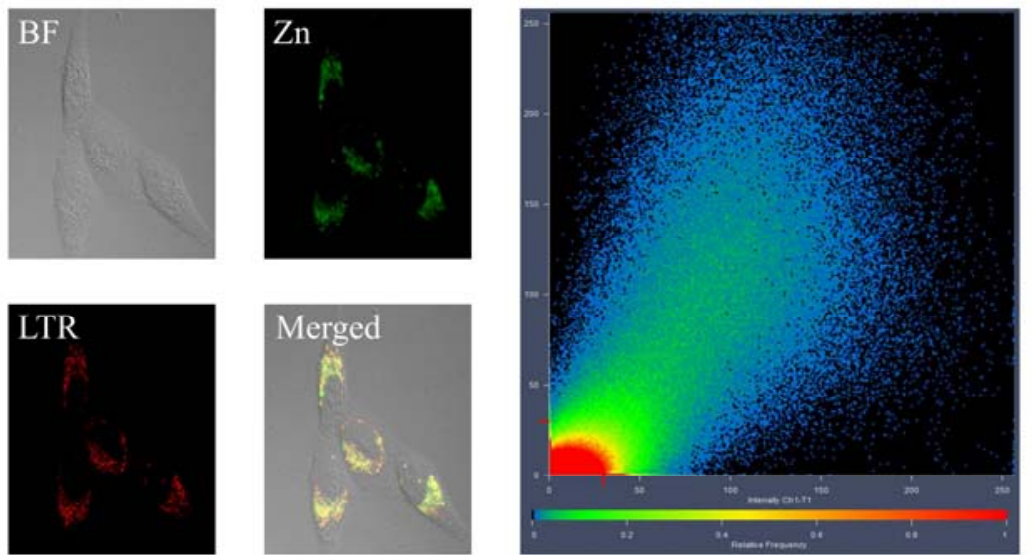

b)

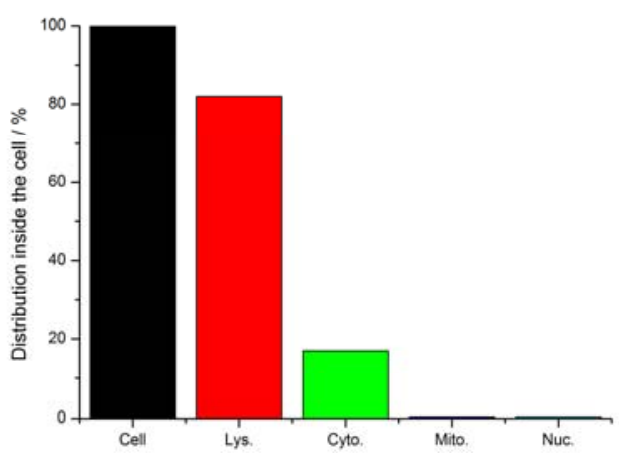

Figure 7. a) Confocal luminescence image of HeLa cells incubated for $4 \mathrm{~h}$ with 3 -NP (Zn, 10 $\left.\mu \mathrm{M}, \lambda_{\mathrm{ex}}=514 \mathrm{~nm}, \lambda_{\mathrm{em}}=530-610 \mathrm{~nm}\right)$ and LysoTracker Deep Red (LTR, $500 \mathrm{nM}, \lambda_{\mathrm{ex}}=633$ $\left.\mathrm{nm}, \lambda_{\mathrm{em}}=650-720 \mathrm{~nm}\right)$ at $37^{\circ} \mathrm{C}$ in the dark. The Pearson correlation coefficient of $\mathrm{Zn}$ and LTR was found to be 0.62 and the Mander's overlap coefficient 0.83 . b) Sub-cellular distribution $($ Cell $=$ Whole cell, Lys. $=$ Lysosome, Cyto. $=$ Cytoplasm, Mito. $=$ Mitochondria, Nuc. $=$ Nucleus) of 3-NP in HeLa cells after $4 \mathrm{~h}$ incubation in the dark determined after organelle extraction and determination of the amount of $\mathrm{Zn}$ inside each organelle by ICP-MS.

\section{D Multicellular Tumor Spheroid Penetration of 3-NP}

For further evaluation of the imaging properties of 3-NP, its fluorescence in 3D multicellular tumor spheroids (MCTS) was investigated. Worthy of note, the application of many investigated molecules for diagnosis or therapy is partially limited due to compromised delivery. ${ }^{45-48}$ Therefore, in this study, the penetration of 3-NP towards large MCTS with a diameter of $800 \mu \mathrm{M}$ was investigated by confocal laser scanning 
microscopy. As the luminescence signal was measurable at every depth (Figure S40), a full penetration of the particles was confirmed.

\section{Selectivity assay of 3-NP between cancerous and non-cancerous cells}

As 3-NP is mainly taken up through the SMVT transporter, these nanoparticles could show a significant cancer cell selectivity. The targeting effect of 3-NP was investigated by mixing transfected cancerous and non-transfected non-cancerous human lung cells. More precisely, cancerous adenocarcinomic human alveolar basal epithelial cells (A549), which have a biotin receptor, were transfected with the fluorescence protein mCherry and mixed with non-cancerous human lung fibroblasts (HLF) cells. Not successfully transfected cells were removed using an antibiotic (G-418). Using confocal laser scanning microscopy (Figure 8), we could show that 3-NP was only internalised in the A549 cells, which were transfected with mCherry, demonstrating its ability as a cancer cell selective imaging agent.
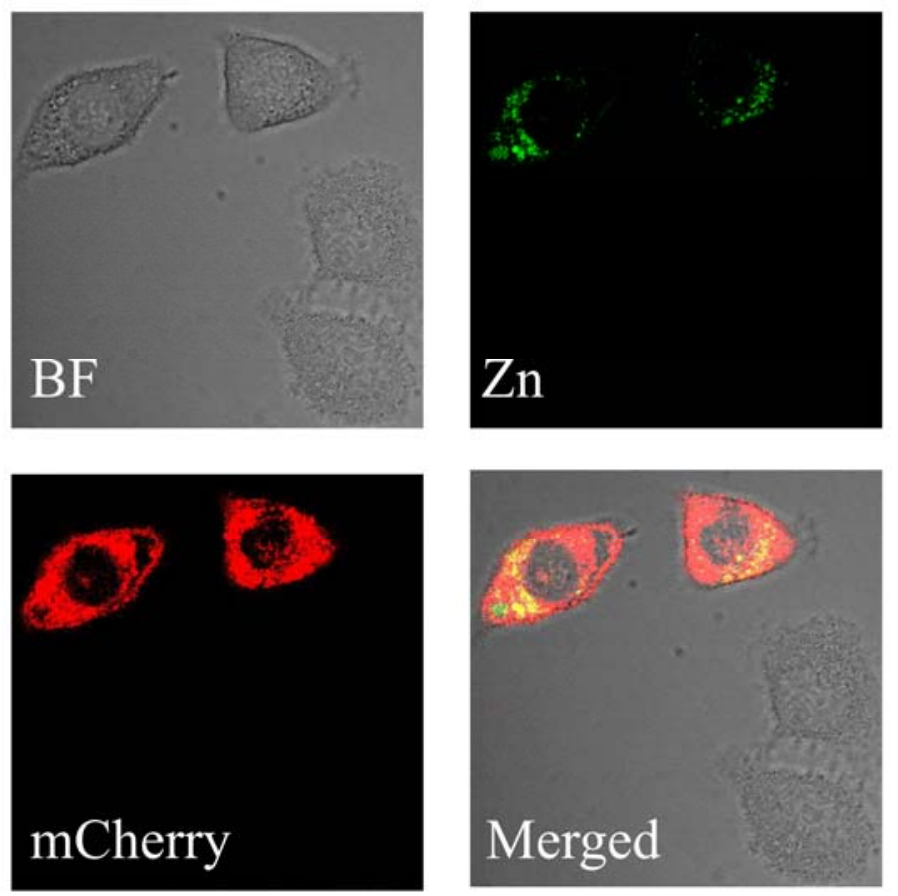

Figure 8. Confocal luminescence image of a mixture of mCherry $\left(\lambda_{\mathrm{ex}}=633 \mathrm{~nm}, \lambda_{\mathrm{em}}=650\right.$ $720 \mathrm{~nm}$ ) transfected cancerous adenocarcinomic human alveolar basal epithelial cells (A549) 
and non-cancerous human lung fibroblasts (HLF) cells incubated for $4 \mathrm{~h}$ with $\mathbf{3}-\mathbf{N P}$ (Zn, 10 $\left.\mu \mathrm{M}, \lambda_{\mathrm{ex}}=514 \mathrm{~nm}, \lambda_{\mathrm{em}}=530-610 \mathrm{~nm}\right)$ at $37^{\circ} \mathrm{C}$ in the dark.

\section{CONCLUSIONS}

In summary, we have prepared a series of bis(dipyrrinato)zinc(II) complexes as imaging probes and evaluated in-depth their photophysical and biological properties. The compounds were found to have a strong fluorescence in apolar environments whereas their fluorescence was quenched in polar solvents. The complexes were found to majorly accumulate in the cytoplasm of HeLa cells by passive diffusion. To overcome the limitation of these compounds (e.g., quenching of the excited state in water, water solubility problems and poor selectivity for cancer cells), the lead compound $\mathbf{3}$ was encapsulated in a polymer matrix with a biotin end group. The generated nanoparticles were found to have a bright luminescence, to selectively accumulate in the lysosomes of cancer cells and to fully penetrate $3 \mathrm{D}$ MCTS. As a benefit from the biotin targeting moiety, the nanoparticles selectively accumulated in cancerous cells over non-cancerous cells. Overall, we strongly believe that this class of compounds and their corresponding nanoparticles have a great potential as bright, selective imaging probes for cancer cells.

\section{ASSOCIATED CONTENT}

Supporting Information:

The Supporting Information is available free of charge on the ACS Publications website at DOI:

Accession Codes:

CCDC 1937531 (for 3), CCDC 1937532 (for dipyrrin_1), CCDC 1937533 (for 2) and CCDC 1937534 (for 4) contain the supplementary crystallographic data for these compounds, and can 
be obtained free of charge from the Cambridge Crystallographic Data Centre via www.ccdc.cam.ac.uk/data_request/cif.

\section{AUTHOR INFORMATION}

Corresponding author:

Email: $\quad$ ceschh@mail.sysu.edu.cn, $\quad$ Tel. $\quad+86 \quad$ 2084110613, $\quad$ Email: gilles.gasser@chimieparistech.psl.eu; Tel.+33 144275602.

ORCID:

Johannes Karges: 0000-0001-5258-0260

Olivier Blacque: 0000-0001-9857-4042

Hui Chao: 0000-0003-4153-5303

Gilles Gasser: 0000-0002-4244-5097

\section{ACKNOWLEDGEMENT}

This work was financially supported by an ERC Consolidator Grant PhotoMedMet to G.G. (GA 681679), has received support under the program "Investissements d'Avenir" launched by the French Government and implemented by the ANR with the reference ANR-10-IDEX-0001-02 PSL (G.G.), the National Science Foundation of China (Nos. 21525105 and 21778079 for H.C.) and the 973 Program (No. 2015CB856301 for H.C.).

\section{REFERENCES}


1. Rao, J.; Dragulescu-Andrasi, A.; Yao, H., Fluorescence imaging in vivo: recent advances. Curr. Opin. Biotechnol. 2007, 18 (1), 17-25.

2. Leblond, F.; Davis, S. C.; Valdés, P. A.; Pogue, B. W., Pre-clinical whole-body fluorescence imaging: Review of instruments, methods and applications. $J$. Photochem. Photobiol. B. 2010, 98 (1), 77-94.

3. Loudet, A.; Burgess, K., BODIPY Dyes and Their Derivatives: Syntheses and Spectroscopic Properties. Chem. Rev. 2007, 107 (11), 4891-4932.

4. Benniston, A. C.; Copley, G., Lighting the way ahead with boron dipyrromethene (Bodipy) dyes. Phys. Chem. Chem. Phys. 2009, 11 (21), 4124-4131.

5. Wagner, R. W.; Lindsey, J. S., Boron-dipyrromethene dyes for incorporation in synthetic multi-pigment light-harvesting arrays. Pure Appl. Chem. 1996, 68 (7), 13731380.

6. Yee, M. C., Fas, S. C.; Stohlmeyer, M. M.; Wandless, T. J.; Cimprich, K. A., A cell-permeable, activity-based probe for protein and lipid kinases. J. Biol. Chem. 2005, 280 (32), 29053-29059.

7. Karolin, J., Johansson, L. B. A., Strandberg, L., Ny, T., Fluorescence and Absorption Spectroscopic Properties of Dipyrrometheneboron Difluoride (BODIPY) Derivatives in Liquids, Lipid Membranes, and Proteins. J. Am. Chem. Soc. 1994, 116 (17), 7801-7806.

8. Boens, N.; Leen, V.; Dehaen, W., Fluorescent indicators based on BODIPY. Chem. Soc. Rev. 2012, 41 (3), 1130-1172.

9. Rezende, L. C. D., Emery, F. S., A Review of the Synthetic Strategies for the Development of BODIPY Dyes for Conjugation with Proteins. Orbital: Electron. J. 2013, $5(1)$.

10. Villemin, E., Ong, Y. C., Thomas, C. M., Gasser, G., Polymer encapsulation of ruthenium complexes for biological and medicinal applications. Nat. Rev. Chem. 2019, 3, 261-282.

11. Larson, N., Ghandehari, H., Polymeric Conjugates for Drug Delivery. Chem. Mater. 2012, 24 (5), 840-853.

12. Steichen, S. D., Caldorera-Moore, M.; Peppas, N. A., A review of current nanoparticle and targeting moieties for the delivery of cancer therapeutics. Eur. J. Pharm. Sci. 2013, 48 (3), 416-427.

13. Sakamoto, R.; Iwashima, T.; Tsuchiya, M.; Toyoda, R.; Matsuoka, R.; Kögel, J. F.; Kusaka, S.; Hoshiko, K.; Yagi, T.; Nagayama, T., New aspects in bis and tris (dipyrrinato) metal complexes: bright luminescence, self-assembled nanoarchitectures, and materials applications. J. Mater. Chem. A 2015, 3 (30), 1535715371.

14. Baudron, S. A., Luminescent dipyrrin based metal complexes. Dalton Trans. 2013, 42 (21), 7498-7509.

15. Wood, T. E.; Thompson, A., Advances in the Chemistry of Dipyrrins and Their Complexes. Chem. Rev. 2007, 107 (5), 1831-1861.

16. Sazanovich, I. V.; Kirmaier, C.; Hindin, E.; Yu, L.; Bocian, D. F.; Lindsey, J. S.; Holten, D., Structural Control of the Excited-State Dynamics of Bis(dipyrrinato)zinc Complexes: Self-Assembling Chromophores for Light-Harvesting Architectures. J. Am. Chem. Soc. 2004, 126 (9), 2664-2665.

17. Trinh, C.; Kirlikovali, K.; Das, S.; Ener, M. E.; Gray, H. B.; Djurovich, P.; Bradforth, S. E.; Thompson, M. E., Symmetry-Breaking Charge Transfer of Visible Light Absorbing Systems: Zinc Dipyrrins. J. Phys. Chem. C 2014, 118 (38), 2183421845. 
18. Kusaka, S.; Sakamoto, R.; Kitagawa, Y.; Okumura, M.; Nishihara, H., An extremely bright heteroleptic bis (dipyrrinato) zinc (II) complex. Chem. Asian J. 2012, 7 (5), 907-910.

19. Sakamoto, R.; Kusaka, S.; Kitagawa, Y.; Kishida, M.-a.; Hayashi, M.; Takara, Y.; Tsuchiya, M.; Kakinuma, J.; Takeda, T.; Hirata, K., Fluorescent azadipyrrinato zinc (ii) complex: hybridisation with a dipyrrinato ligand. Dalton Trans. 2012, 41 (46), 1403514037.

20. Lee, S.; Seok, C.-H.; Park, Y.; Lee, A.; Jung, D. H.; Choi, S.-H.; Park, J., Enforced Effects of Side Group Substitution Position on Luminescence Properties; Synthesis of Bis(dipyrrinato)zinc Complex Derivatives. Mol. Cryst. Liq. Cryst. 2010, 531 (1), 365-372.

21. Sakamoto, R.; Iwashima, T.; Kögel, J.F.; Kusaka, S.; Tsuchiya, M.; Kitagawa, Y.; Nishihara, H., Dissymmetric Bis(dipyrrinato)zinc(II) Complexes: Rich Variety and Bright Red to Near-Infrared Luminescence with a Large Pseudo-Stokes Shift. J. Am. Chem. Soc. 2016, 138 (17), 5666-5677.

22. Tsuchiya, M.; Sakamoto R.; Shimada, M.; Yamanoi, Y.; Hattori, Y.; Sugimoto, K.; Nishibori, E.; Nishihara, H.; Bis (dipyrrinato) zinc (II) complexes: emission in the solid state. Inorg. Chem. 2016, 55 (12), 5732-5734.

23. Maiti, S.; Paira, P., Biotin conjugated organic molecules and proteins for cancer therapy: A review. Eur. J. Med. Chem. 2018, 145, 206-223.

22. Tripodo, G.; Mandracchia, D.; Collina, S.; Rui, M.; Rossi, D., New perspectives in cancer therapy: the biotin-antitumor molecule conjugates. Med. Chem. 2014, 8, 14.

25. Roth, K. S., Biotin in clinical medicine-a review. Am. J. Clin. Nutr. 1981, 34 (9), 1967-1974.

26. Rigaku Oxford Diffraction 2015.

27. Clark, R.; Reid, J., The analytical calculation of absorption in multifaceted crystals. Acta Crystallogr. Sect. A: Found. Crystallogr. 1995, 51 (6), 887-897.

28. CrysAlisPro (version 1.171.39.13a), Rigaku Oxford Diffraction 2016.

29. Dolomanov, O. V.; Bourhis, L. J.; Gildea, R. J.; Howard, J. A. K.; Puschmann, H., OLEX2: a complete structure solution, refinement and analysis program. J. Appl. Crystallogr. 2009, 42 (2), 339-341.

30. Sheldrick, G. M., SHELXT-Integrated space-group and crystal-structure determination. Acta Cryst. A 2015, 71 (1), 3-8.

31. Sheldrick, G. M., Crystal structure refinement with SHELXL. Acta Cryst. C 2015, 71 (1), 3-8.

32. Macrae, C. F.; Edgington, P. R.; McCabe, P.; Pidcock, E.; Shields, G. P.; Taylor, R.; Towler, M.; Streek, J. v. d., Mercury: visualization and analysis of crystal structures. J. Appl. Crystallogr. 2006, 39 (3), 453-457.

33. Brouwer, A. M., Standards for photoluminescence quantum yield measurements in solution (IUPAC Technical Report). Pure Appl. Chem. 2011, 83 (12), 2213-2228

34. Spek, A. L.; PLATON SQUEEZE: a tool for the calculation of the disordered solvent contribution to the calculated structure factors. Acta Cryst. C. 2015, 71, 9-18.

35. Basu, U.; Karges, J.; Chotard, F.; Balan, C.; Le Gendre, P.; Gasser, G.; Bodio, E.; Malacea Kabbara, R., Investigation of photo-activation on Ruthenium(II)-arene complexes for the discovery of potential selective cytotoxic agents. Polyhedron 2019, in press, doi.org/10.1016/j.poly.2019.02.041. 
36. Renfrew, A. K.; Karges, J.; Scopelliti, R.; Bobbink, F. D.; Nowak-Sliwinska, P.; Gasser, G.; Dyson, P., Towards Light Activated Ruthenium-Arene (RAPTA-type) Prodrug Candidates. ChemBioChem 2019, in press, 10.1002/cbic.201900236.

37. Karges, J.; Goldner, P.; Gasser, G., Synthesis, Characterization, and Biological Evaluation of Red-Absorbing Fe (II) Polypyridine Complexes. Inorganics 2019, 7 (1), 4.

38. Karges, J.; Blacque, O.; Jakubaszek, M.; Goud, B.; Goldner, P.; Gasser, G., Systematic investigation of the antiproliferative activity of a series of ruthenium terpyridine complexes. J. Inorg. Biochem. 2019, 198, 110752.

39. Dąbrowski, J. M.; Pucelik, B.; Pereira, M. M.; Arnaut, L. G.; Stochel, G., Towards tuning PDT relevant photosensitizer properties: comparative study for the free and Zn2+ coordinated meso-tetrakis[2,6-difluoro-5-(N-methylsulfamylo)phenyl]porphyrin. J. Coord. Chem. 2015, 68 (17-18), 3116-3134.

40. Pavani, C.; Uchoa, A. F.; Oliveira, C. S.; lamamoto, Y.; Baptista, M. S., Effect of zinc insertion and hydrophobicity on the membrane interactions and PDT activity of porphyrin photosensitizers. Photochem. Photobiol. Sci. 2009, 8 (2), 233-240.

41. Alford, R.; Simpson, H. M.; Duberman, J.; Hill, G. C.; Ogawa, M.; Regino, C.; Kobayashi, H.; Choyke, P. L., Toxicity of Organic Fluorophores Used in Molecular Imaging: Literature Review. Mol. Imaging 2009, 8 (6), 341-354.

42. Vadlapudi, A. D.; Vadlapatla, R. K.; Pal, D.; Mitra, A. K., Biotin uptake by T47D breast cancer cells: functional and molecular evidence of sodium-dependent multivitamin transporter (SMVT). Int. J. Pharm. 2013, 441 (1-2), 535-543.

43. Zang, Q.; Yu, J.; Yu, W.; Qian, J.; Hu, R.; Tang, B. Z., Red-emissive azabenzanthrone derivatives for photodynamic therapy irradiated with ultralow light power density and two-photon imaging. Chem. Sci. 2018, 9 (23), 5165-5171.

44. Karges, J.; Basu, U.; Blacque, O.; Chao, H.; Gasser, G., Polymeric Encapsulation of Novel Homoleptic Bis(dipyrrinato) Zinc(II) Complexes with Long Lifetimes for Applications as Photodynamic Therapy Photosensitisers. Angew. Chem. Int. Ed., accepted, DOI: https://doi.org/10.1002/anie.201907856.45. Pluen, A.; Boucher, Y.; Ramanujan, S.; McKee, T. D.; Gohongi, T.; di Tomaso, E.; Brown, E. B.; Izumi, Y.; Campbell, R. B.; Berk, D. A.; Jain, R. K., Role of tumor-host interactions in interstitial diffusion of macromolecules: Cranial vs. subcutaneous tumors. Proc. Natl. Acad. Sci. 2001, 98 (8), 4628-4633.

46. Netti, P. A.; Berk, D. A.; Swartz, M. A.; Grodzinsky, A. J.; Jain, R. K., Role of Extracellular Matrix Assembly in Interstitial Transport in Solid Tumors. Cancer Res. 2000, 60 (9), 2497-2503.

47. Friedrich, J.; Seidel, C.; Ebner, R.; Kunz-Schughart, L. A., Spheroid-based drug screen: considerations and practical approach. Nat. Protoc. 2009, 4, 309.

48. Goodman, T. T.; Ng, C. P.; Pun, S. H., 3-D Tissue Culture Systems for the Evaluation and Optimization of Nanoparticle-Based Drug Carriers. Bioconjugate Chem. 2008, 19 (10), 1951-1959. 


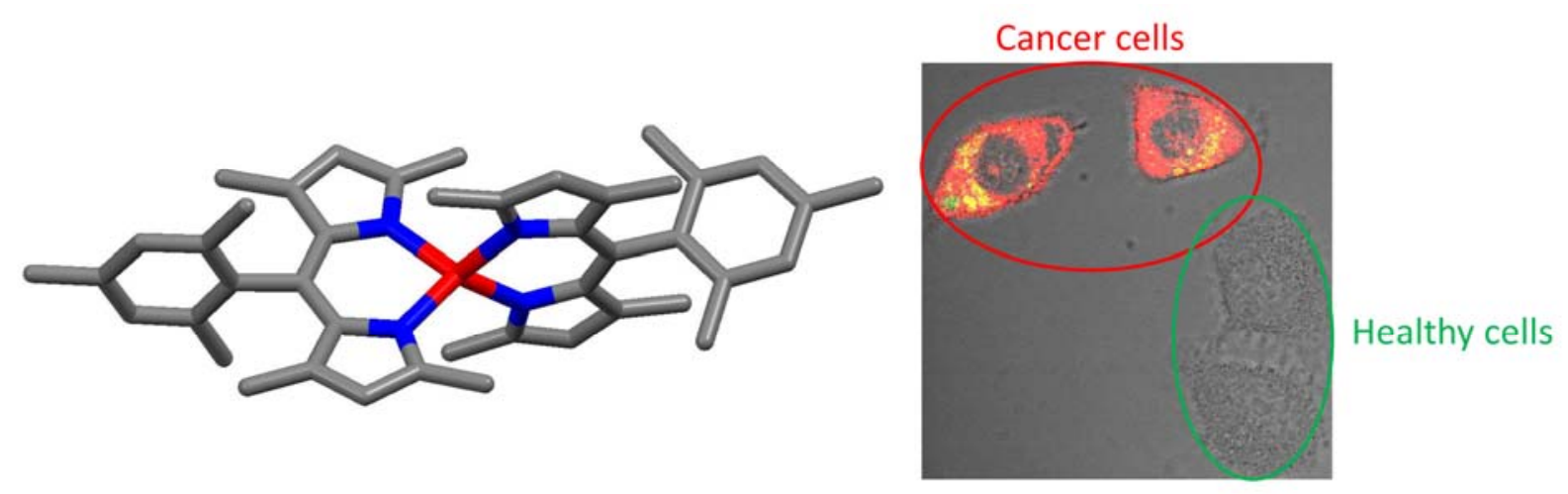

\section{Synopsis:}

Poor aqueous solubility and quenching effects in water are major drawbacks for some of the imaging agents currently investigated. Herein, we report the synthesis, characterization and biological evaluation of bis(dipyrrinato) Zinc(II) complexes. Thanks to encapsulation in a polymer containing a targeting moiety, the formed nanoparticles were found to overcome these limitations and to selectively accumulate in the lysosomes of cancerous cells. 